\title{
Biotic and abiotic resistance inducers for controlling white rust in rocket (Eruca sativa)
}

\author{
Indutores de resistência bióticos e abióticos para \\ controle de ferrugem branca em rúcula (Eruca sativa)
}

\author{
Luciana lurkiv' 1 (1) (orcid.org/0000-0001-9460-163X) \\ Barbara Eckstein 1 (1) (orcid.org/0000-0002-9734-6758) \\ Eloisa Lorenzetti ${ }^{1 *}$ (1) (orcid.org/0000-0002-2363-2065) \\ José Renato Stangarlin' ${ }^{1}$ (orcid.org/0000-0001-8601-9439)
}

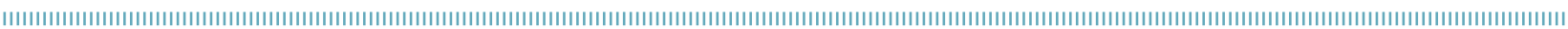

\begin{abstract}
Induced resistance emerges as an alternative method for controlling plant diseases. This study aimed to evaluate the efficacy of biotic and abiotic resistance inducers for controlling white rust in rocket (Eruca sativa), as well as biochemical changes (peroxidase) and fitness costs. The experiments were developed with the abiotic inducers acibenzolar-S-methyl (ASM) $(12.5,25$, and $\left.50 \mathrm{mg} \mathrm{ai} \mathrm{L}^{-1}\right)$ and citrus biomass (CB) $(0.1,0.25$, and $0.5 \%)$, as well as with the biotic ones Saccharomyces cerevisiae $(25 \mathrm{mg} \mathrm{mL}$ ${ }^{1}$ ), Bacillus thuringiensis ( $25 \mathrm{mg}$ p.c. $\mathrm{mL}^{-1}$ ), Saccharomyces boulardii (25 $\mathrm{mg} \mathrm{mL}^{-1}$ ), and phosphorylated mannan oligosaccharide (PMO) $(0.25 \%)$, in preventive and curative interventions. Fungicide mancozeb (1.6 g ai L-1), Bordeaux mixture (1\%), and water were the control treatments. Leaf samples were collected $3,7,11,15$, and 19 days after the treatments to determine peroxidases and assess the severity and production. Concerning abiotic inducers, all doses of ASM and CB 0.5\% (preventive) and $\mathrm{CB} 0.25 \%$ (curative) reduced the severity of white rust, whereas, among biotic inducers, only PMO applied preventively controlled the disease. Peroxidase activity was higher for CB $0.25 \%$ and ASM $50 \mathrm{mg} \mathrm{L}^{-1}$. Bordeaux mixture induced higher peroxidase activity.
\end{abstract}

KEYWORDS: Albugo candida; alternative control; Eruca sativa; inducted resistance.
RESUMO: A indução de resistência surge como um método alternativo para o controle de doenças em plantas. O objetivo deste trabalho foi avaliar a eficiência de indutores de resistência bióticos e abióticos no controle de ferrugem branca em rúcula (Eruca sativa), bem como alterações bioquímicas (peroxidase) e o impacto na produção. Foram desenvolvidos experimentos com os indutores abióticos acibenzolarS-metil (ASM) (12,5; 25 e 50 mg i.a. L $\left.{ }^{-1}\right)$ e biomassa cítrica (BC) $(0,1 ; 0,25$ e $0,5 \%)$, e os bióticos Saccharomyces cerevisiae (25 mg p.c. $\left.\mathrm{mL}^{-1}\right)$, Bacillus thuringiensis $\left(25 \mathrm{mg}\right.$ p.c. $\left.\mathrm{mL}^{-1}\right)$, Saccharomyces boulardii (25 mg p.c. $\mathrm{mL}^{-1}$ ) e manano-oligossacarídeo fosforilado (MOF) $(0,25 \%)$, sendo aplicados preventiva e curativamente. Como controles foram utilizados o fungicida mancozeb $\left(1,6 \mathrm{~g}\right.$ i.a. $\left.\mathrm{L}^{-1}\right)$, calda bordalesa (1\%) e água. Amostras de folhas foram coletadas aos 3, 7, 11, 15 e 19 dias após os tratamentos para a determinação de peroxidases, e avaliaçóes de severidade e produçáo. Entre os indutores abióticos, todas as doses de ASM e BC 0,5\% (preventivamente) e BC 0,25\% (curativamente) reduziram a severidade da ferrugem branca, enquanto entre os indutores bióticos, apenas o MOF aplicado preventivamente, controlou a doença. A atividade de peroxidase foi superior para BC $0,25 \%$ e ASM $50 \mathrm{mg} \mathrm{L}^{-1}$. O tratamento com calda bordalesa também incrementou a atividade de peroxidase.

PALAVRAS-CHAVE: Albugo cândida; controle alternativo; Eruca sativa; indução de resistência. 


\section{INTRODUCTION}

Rocket or arugula (Eruca sativa Miller) is an annual herbaceous vegetable, originated and domesticated in the Mediterranean and West Asia (REGHIN, 2005). White rust is one of its main diseases, often affecting this crop. It is caused by the biotrophic pathogen Albugo candida (MEENA et al., 2005), which belongs to the family Albuginaceae. In some cases, the damages are substantial due to the pathogen aggressiveness and the lack of effective control measures.

The principal loss related to white rust on rocket is the non-possibility of commercialization of the symptomatic leaves, leading to significant damage to production, given the depreciation and rejection by the consumer market. Preventing the penetration and establishment of the pathogen in the cultivation area is still the best way to control the disease (STANGARLIN; IURKIV, 2008).

Induced resistance is a method that consists of increasing the plant resistance level using biotic or abiotic agents before infection by pathogens, and without any change in the plant genome (PASCHOLATI; DALIO, 2018). Many studies have been developed intending to find non-antibiotic protective compounds capable of activating host defense mechanisms in various plants (MÉTRAUX, 2007). Therefore, the great potential of such compounds is recognized as a new generation of products for disease control, reducing the use of fungicides and enabling the use of biocontrol agents (LYON; NEWTON, 1997).

Peroxidases (EC1.11.1.7) are enzymes often related to the induced resistance process (CAVALCANTI et al., 2005), participating in the final stage of lignin synthesis (TAIZ; ZEIGER, 2004). This substance or lignification process can influence the growth of pathogens through chemical changes in host cell walls (VAN LOON; VAN STRIEN, 1999). Peroxidases have also been associated with several defenserelated processes, such as hypersensitivity responses, suberization, and production of phytoalexins (NICHOLSON; HAMMERSCHMIDT, 1992).

This study aimed to investigate the efficacy of biotic and abiotic products in the control of white rust on rocket and the induction of peroxidases by these treatments, in addition to their influence on plant yield.

\section{MATERIAL AND METHODS}

Two experiments were carried out under field conditions using $1.5 \times 0.8 \mathrm{~m}$ experimental plots. Seeds of rocket were sown in $0.2 \mathrm{~m}$ spaced lines, maintaining $0.05 \mathrm{~m}$ between seedlings after thinning. The two central lines were considered a useful plot area, disregarding $0.1 \mathrm{~m}$ at the ends.
The abiotic inducers were acibenzolar-S-methyl (ASM) $\left(12.5,25\right.$, and $\left.50 \mathrm{mg} \mathrm{L}^{-1}\right)$ and citrus biomass (CB) $(0.1,0.25$, and $0.5 \%$ ), whereas the biotic ones were Saccharomyces cerevisiae [25 mg commercial product (cp) $\mathrm{mL}^{-1}$ ], Bacillus thuringiensis (25 mg cp mL-1), Saccharomyces boulardii $\left(25 \mathrm{mg} \mathrm{cp} \mathrm{mL}^{-1}\right)$, and phosphorylated mannan oligosaccharide (PMO) $(0.25 \%)$. The control treatments were water and fungicide mancozeb $\left(1.6 \mathrm{~g} \mathrm{~L}^{-1}\right)$, and water and Bordeaux mixture (1\%) for abiotic and biotic inducer assays, respectively. The treatments were applied both preventively and curatively.

The evaluation of the preventive effect consisted of treating $50 \%$ of the plants of each plot 19 days after sowing (DAS) by foliar spraying. The second application of the products in these plants coincided with the first application in the remaining plants when the first symptoms of the disease appeared (curative effect) (32 DAS).

Three days after the first treatment (DAT), all plants of the experimental plot were inoculated using a suspension with $1 \times 10^{4}$ sporangia $\mathrm{mL}^{-1}$ [made with water plus Tween $\left.80\left(100 \mu \mathrm{L} \mathrm{L}^{-1}\right)\right]$. After the onset of the first symptoms, the plants were evaluated for disease severity every two days, using a diagrammatic scale made for this purpose.

Leaf samples were collected 3, 7, 11, 15, and 19 DAT to assess the enzymatic peroxidase activity and total protein content. At each treatment replication, 10 leaf discs with $1.5 \mathrm{~cm}$ in diameter were collected and stored at $-20^{\circ} \mathrm{C}$. The leaf samples were homogenized in $2 \mathrm{~mL}$ of phosphate buffer $0.01 \mathrm{M}$ ( $\mathrm{pH} 6.0$ ), using previously cooled porcelain mortar. The homogenate was centrifuged at $6,000 \mathrm{~g}$ for 20 minutes, and the supernatant, which contained soluble proteins, was stored at $4^{\circ} \mathrm{C}$ for later biochemical analyses.

Peroxidase activity was determined at $30^{\circ} \mathrm{C}$ using the direct spectrophotometric method by HAMMERSCHMIDT et al. (1982) by mixing $2.9 \mathrm{~mL}$ from substrate to enzyme [306 $\mu \mathrm{L}$ hydrogen peroxide, $12.5 \mathrm{~mL}$ of $2 \%$ guaiacol, and $87.5 \mathrm{~mL}$ phosphate buffer $0.01 \mathrm{M}(\mathrm{pH} 6.0)]$ and $0.1 \mathrm{~mL}$ of the sample. The absorbance (abs) was measured at $470 \mathrm{~nm}$ for 2 minutes, and the peroxidase activity was established by the variation of the extreme values present in the linear increment range. This variation was expressed as $\Delta \mathrm{abs} / \mathrm{min}^{-1} / \mathrm{mg}$ protein ${ }^{-1}$.

To identify the total protein content, $600 \mu \mathrm{L}$ phosphate buffer $0.01 \mathrm{M}$ (pH 6,0), $200 \mu \mathrm{L}$ of the sample, and $200 \mu \mathrm{L}$ Bradford reagent were stirred, and, after 5 minutes of incubation, the absorbance was measured at $595 \mathrm{~nm}$. Data were plotted on a standard protein curve and expressed as $\mathrm{mg}$ protein $\mathrm{mL}^{-1}$ (BRADFORD, 1976).

Five whole plants were collected per plot to evaluate the rocket yield, as well as the fresh and dry masses and the number of leaves. Fresh mass was evaluated immediately after harvest, whereas for dry mass, the samples were kept at $60^{\circ} \mathrm{C}$ until constant weight. The number of leaves considered the ones greater than $5 \mathrm{~cm}$ per plant. 
We analyzed the data by variance and, when significant, performed the Tukey test at $1 \%$ error probability, using the software Sisvar (FERREIRA, 2011). When necessary, data were transformed into the root of $\mathrm{x}+1$.

\section{RESULTS AND DISCUSSION}

Regarding white rust severity in rocket (Table 1), both preventive and curative treatments with abiotic inducers were efficient in controlling the disease. Although no treatment provided full control, all doses of ASM (both preventive and curative), CB $0.5 \%$ (preventive), and CB 0.25\% (curative) presented very satisfactory control, not differing from the fungicide (Table 1).

RODRIGUES et al. (2006) obtained similar data when evaluating the efficacy of abiotic resistance inducers in the control of Fusarium oxysporum f.sp. tracheiphilum in cowpea. The authors found that ASM $5.0 \mathrm{mg} \mathrm{mL}^{-1}$ showed significantly lower severity.

COSTA et al. (2007) evaluated alternative products in the control of coffee rust and verified the efficacy of ASM $\left(1 \mathrm{~g} \mathrm{~L}^{-1}\right)$ and $\mathrm{CB}\left(0.25 \mathrm{~mL} \mathrm{~L}^{-1}\right)$, as ASM reduced $77 \%$ of the infection caused by Hemileia vastatrix. However, ROSA et al. (2007) studied the effects of inducers on mildew control in Vitis labrusca and reported that CB $1.5 \mathrm{~mL} \mathrm{~L}^{-1}$ was not effective. At the same time, CAVALCANTI et al. (2006) revealed that ASM $\left(5 \mathrm{~mL} \mathrm{~L}^{-1}\right)$ was $47.7 \%$ effective against Xanthomonas vesicatoria in tomato plants.

DANTAS et al. (2004) investigated the efficacy of resistance inducers in papaya protection against postharvest rot, reporting a significant reduction in the incidence and the area under the disease progress curve (AUDPC) of anthracnose with ASM (50 and $100 \mu \mathrm{g} \mathrm{L}^{-1}$ ). The same was observed for Lasiodiplodia, as it reduced the incidence of the disease by $50 \%$, on average, in addition to being effective in the control of Fusarium rot.

Nevertheless, results obtained by SOARES et al. (2004) evidenced that ASM $\left(100 \mu \mathrm{g} \mathrm{mL}^{-1}\right)$ was ineffective, both in inducing resistance to Curtobacterium wilt in the susceptible bean cultivar IAC Carioca and increasing resistance levels in cultivars IAC Carioca Akytã and IAC Carioca Pyatá.

Concerning biotic inducers (Table 2), the PMO (0.25\%) and Bordeaux mixture (1\%) treatments significantly reduced the severity of the disease compared to water control when applied preventively. Although not significantly lower, the disease control of the $S$. cerevisiae $\left(25 \mathrm{mg} \mathrm{mL}^{-1}\right)$, B. thuringiensis (25 $\left.\mathrm{mg} \mathrm{mL}^{-1}\right)$, and $S$. boulardii $\left(25 \mathrm{mg} \mathrm{mL}^{-1}\right)$ treatments presented average severity about $52 \%$ lower than that of water control. With respect to curative control, only Bordeaux mixture (1\%) presented significantly reduced severity (Table 2).

ROSA et al. (2007) evaluated the effect of inducers on mildew control in Vitis labrusca and revealed that the application of Agro-Mos + Crop-Set (1 and $\left.0.1 \mathrm{~mL} \mathrm{~L}^{-1}\right)$ resulted in greater disease control, reducing the severity by 37,36 , and $18 \%$ in the three areas studied.

DANTAS et al. (2004) verified the efficacy of AgroMos $\left(500\right.$ and $\left.750 \mu \mathrm{L} \mathrm{mL}^{-1}\right)$ in the control of anthracnose in papaya; however, the same treatments were not effective in controlling Lasiodiplodia rot.

PICCININ et al. (2005) evaluated the effect of S. cerevisiae on sorghum yield and the severity of leaf diseases and noted that weekly applications reduced the speed of progress of anthracnose disease in magnitude similar to that of treatment with a fungicide. Productivity increased using the same treatments compared to the inoculated control. In a field inoculated with Exserohilum turcicum, the amount of disease decreased even with a single application to the yeast. However, there was no significant increase in productivity.

Table 1. Severity of white rust (Albugo candida) in rocket (Eruca sativa) treated with abiotic resistance inducers*.

\begin{tabular}{lcc} 
Treatments & \multicolumn{2}{c}{ Severity (\%) } \\
\hline Acibenzolar-S-methyl (ASM) $12.5 \mathrm{mg} \mathrm{L}^{-1}$ & Preventive & Curative \\
\hline Acibenzolar-S-methyl (ASM) $25 \mathrm{mg} \mathrm{L}^{-1}$ & $5.3 \mathrm{bc}$ & $9.2 \mathrm{~b}$ \\
\hline Acibenzolar-S-methyl (ASM) $50 \mathrm{mg} \mathrm{L}^{-1}$ & $4.2 \mathrm{bc}$ & $8.5 \mathrm{~b}$ \\
\hline Citrus biomass (CB) $0.1 \%$ & $2.1 \mathrm{c}$ & $2.8 \mathrm{~b}$ \\
\hline Citrus biomass (CB) $0.25 \%$ & $15.6 \mathrm{ab}$ & $9.8 \mathrm{ab}$ \\
\hline Citrus biomass (CB) $0.5 \%$ & $12.8 \mathrm{abc}$ & $4.4 \mathrm{~b}$ \\
\hline Mancozeb & $9.6 \mathrm{bc}$ & $11.0 \mathrm{ab}$ \\
\hline Water & $7.8 \mathrm{bc}$ & $7.0 \mathrm{~b}$ \\
\hline CV (\%) & $29.2 \mathrm{a}$ & $27.8 \mathrm{a}$ \\
\hline
\end{tabular}

*Averages followed by the same letter in the column do not differ statistically from each other according to the Tukey test $(a=0.01)$. Data transformed into the root of $x+0.5 ; C V$ : coefficient of variation. 
Studying the presence of elicitors in S. cerevisiae and their activity as resistance inducers, LABANCA (2002) found them ineffective against Microsphaera diffusa in soybean plants. Nonetheless, cucumber seedlings treated with protein fractions from this yeast, obtained by affinity chromatography, showed reductions between 50 and $70 \%$ in severity caused by Colletotrichum lagenarium and increase in peroxidase activity.

JESUS et al. (2006) investigated the potential of three different Bacillus thuringiensis isolates and harpin protein in controlling Phyllosticta citricarpa in orange fruits and observed that both were able to control the disease, decreasing the development of new lesions by up to $54 \%$ and the number of pycnids by up to 95\%. Additionally, coffee plants treated with B. thuringiensis ( 4.5 $\times 10^{8}$ cells $\mathrm{mL}^{-1}$ ) and harpin protein (3\%) showed a decrease in the symptoms of rust, reaching $66.3 \%$ for $B t$ (JESUS et al., 2008).
The sum of the specific peroxidase activity for abiotic inducers (Fig. 1) in the different sampling days was statistically superior for CB $0.25 \%$ and ASM $50 \mathrm{mg} \mathrm{L}^{-1}$. This finding indicates a potential induction by these treatments since they were effective in controlling the disease when compared to the water treatment.

Peroxidase activity was superior in the ASM $50 \mathrm{mg} \mathrm{L}^{-1}$ treatment in relation to water control three days after treatment (Fig. 2), not differing, however, from CB $0.25 \%$ and ASM $12.5 \mathrm{mg} \mathrm{L}^{-1}$. Statistical difference was identified again on the second day after the second treatment, i.e., when the pathogen was already present in the plants, with superiority for CB $0.25 \%$ and $\mathrm{CB} 0.5 \%$ (Fig. 2).

RODRIGUES et al. (2006) assessed the effect of $\beta$ aminobutyric acid, ASM $\left(5.0 \mathrm{mg}^{2} \mathrm{~mL}^{-1}\right)$, and chitosan on the

Table 2. Severity of white rust (Albugo candida) in rocket (Eruca sativa) treated with biotic resistance inducers*.

\begin{tabular}{lcc} 
Treatments & \multicolumn{2}{c}{ Severity (\%) } \\
\cline { 2 - 3 } Saccharomyces cerevisiae $\left(25 \mathrm{mg} \mathrm{mL}^{-1}\right)$ & Preventive & Curative \\
\hline Bacillus thuringiensis $\left(25 \mathrm{mg} \mathrm{mL}^{-1}\right)$ & $33.8 \mathrm{ab}$ & $42.1 \mathrm{ab}$ \\
\hline Saccharomyces boulardii $\left(25 \mathrm{mg} \mathrm{mL}^{-1}\right)$ & $37.0 \mathrm{ab}$ & $33.6 \mathrm{ab}$ \\
\hline Phosphorylated mannan oligosaccharide & $35.3 \mathrm{ab}$ & $33.0 \mathrm{ab}$ \\
\hline Bordeaux mixture $(1 \%)$ & $17.0 \mathrm{bc}$ & $39.4 \mathrm{ab}$ \\
\hline Water & $3.8 \mathrm{c}$ & $6.2 \mathrm{~b}$ \\
\hline CV $(\%)$ & $74.3 \mathrm{a}$ & $67.3 \mathrm{a}$ \\
\hline
\end{tabular}

*Averages followed by the same letter in the column do not differ statistically from each other according to the Tukey test $(a=0.01)$. Data transformed into the root of $x+1 ; C V$ : coefficient of variation.

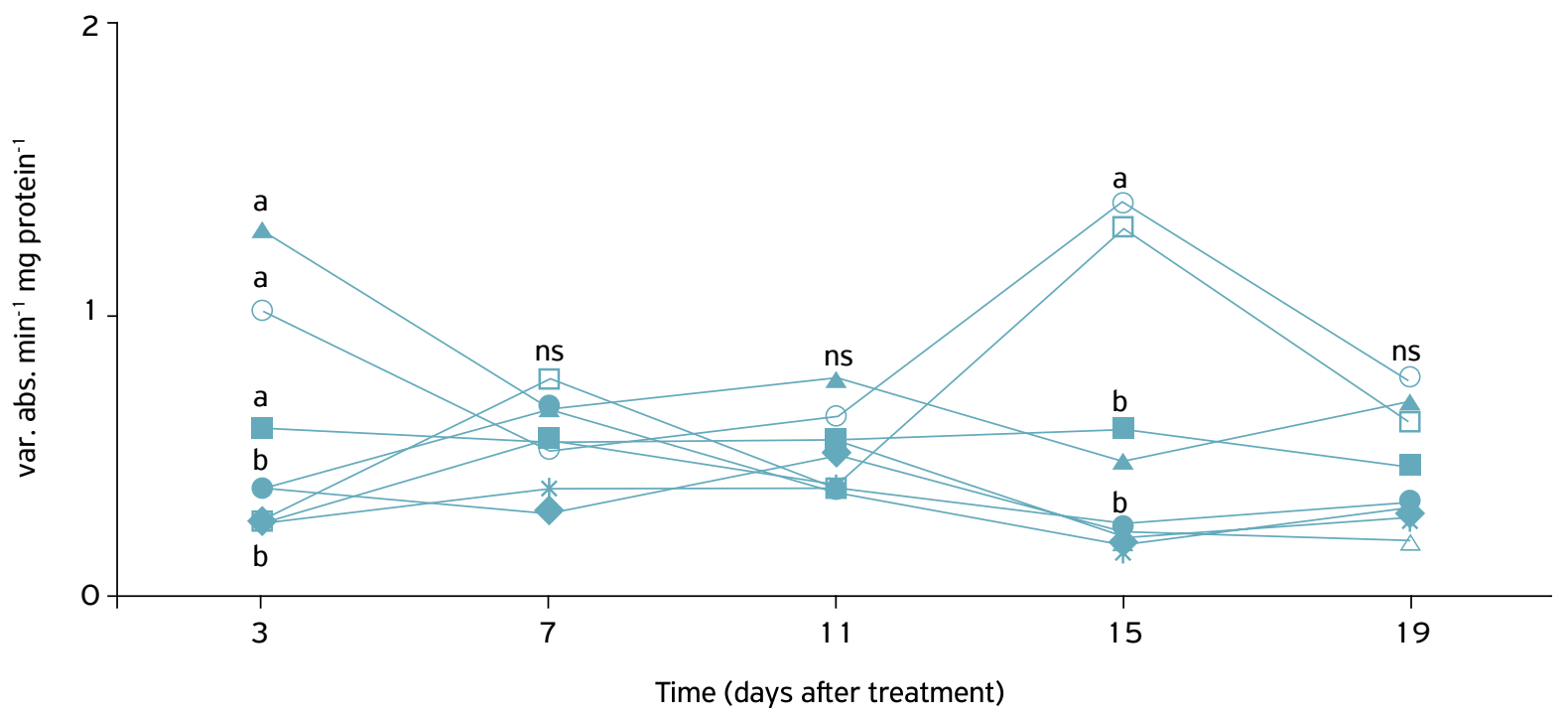

(-): Acibenzolar-S-methyl (ASM) $50 \mathrm{mg} \mathrm{L}^{-1}$; (-): ASM $25 \mathrm{mg} \mathrm{L}^{-1}$; (-): ASM $12.5 \mathrm{mg} \mathrm{L}^{-1}$; ( $\square$ ): Citrus biomass (CB) 0.5\%; ( $\bigcirc$ ): CB 0.25\%; $(\triangle)$ : CB $0.1 \% ;(-)$ : Mancozeb $\left(1.6 \mathrm{~g} \mathrm{~L}^{-1}\right)$; and $(*)$ : Water. Averages, at a given time, followed by the same letter do not differ statistically from each other according to the Tukey test $(a=0.01)$. ns: not significant.

Figure 1. Specific peroxidase activity in rocket (Eruca sativa) treated with abiotic inducers and inoculated with Albugo candida $\left(1 \times 10^{4}\right.$ sporangia $\left./ \mathrm{mL}^{-1}\right)$. 
activity of pathogenesis related-proteins (PR-proteins) in cowpea plants inoculated with Fusarium oxysporum f. sp. tracheiphilum and identified a significant increase in peroxidase activity in the cultivars IPA-206 and BR-17 Gurguéia ten days after inoculation.

CAVALCANTI et al. (2006) revealed that tomato plants sprayed with ASM and CB, without inoculation with Xanthomonas vesicatoria, showed a significant increase in peroxidase activity in leaves four hours after spraying (HAS). In plants sprayed with $\mathrm{CB}$, a sharp rise in peroxidase activity, about 4-fold over control treatments, was observed within 8 to 24 HAS, followed by a decrease in 48 HAS.

Bean cultivars with different levels of resistance sprayed with ASM, both on the leaf and the stem, showed higher peroxidase activity than non-treated ones. At the same time, the product was ineffective in the control of Curtobacterium wilt, which may indicate that other mechanisms or compounds could be involved in the induced resistance in this pathosystem (SOARES et al., 2004).

The sum of the specific peroxidase activity for biotic assays (Fig. 3) was superior in the Bordeaux mixture (1\%) treatment. When analyzing the different sampling days (Fig. 4), the same treatment showed superiority over the others on the sixth day after the first treatment and the second day after the second treatment, indicating an induced peroxidase activity, which could have interfered with the severity of the disease.

LABANCA (2002) used purified elicitors from S. cerevisiae and detected an increase in the peroxidase activity in cucumber seedlings treated and inoculated with C. lagenarium. This increase was verified in the second and third days after inoculation.
Few studies investigated induced resistance in plants by the application of S. boulardii. SCHULZ et al. (2008) identified the ability of yeast of inducing phytoalexin in sorghum mesocotyls and soybean cotyledons, reaching 163 and 192\% increment in relation to the control, respectively. STANGARLIN et al. (2010) also verified the induction of phytoalexin glyceollin in soybean cotyledons and deoxyanthocianidin in sorghum mesocotyls using $S$. boulardii.

Regarding fresh mass, dry mass, and number of leaves, the treatments presented no significant difference in both trials (data not shown), indicating that despite the induced peroxidase activity responses of the plant, production did not decrease. Similar data were reported by SOARES et al. (2004), who found no difference between the reduction in dry mass of bean plants sprayed (32.88\%) and unsprayed (32.20\%) with ASM $\left(100 \mathrm{mg} \mathrm{mL}^{-1}\right)$ and inoculated with Curtobacterium flaccumfaciens pv. flaccumfaciens.

CAVALCANTI et al. (2006) studied the efficacy of ASM and CB in inducing tomato defense response against bacterial wilt and declared that the growth of plants sprayed with ASM $\left(0.2 \mathrm{~g} \mathrm{~L}^{-1}\right)$ did not differ from that of the control plants (healthy). However, tomato plants sprayed with CB showed a reduction in shoot growth, both in the relative growth rate $(1.12$ versus $2.10 \mathrm{~cm}$ day $^{-1}$ in health plants) and the fresh crown mass accumulation (14.35 versus $24.05 \mathrm{~g}$ in healthy plants) 20 days after inoculation.

Aiming to verify the effectiveness of ASM in controlling potato blight, TÖFOLI et al. (2005) reported that the addition of a resistance inducer in the mixture of chlorothalonil

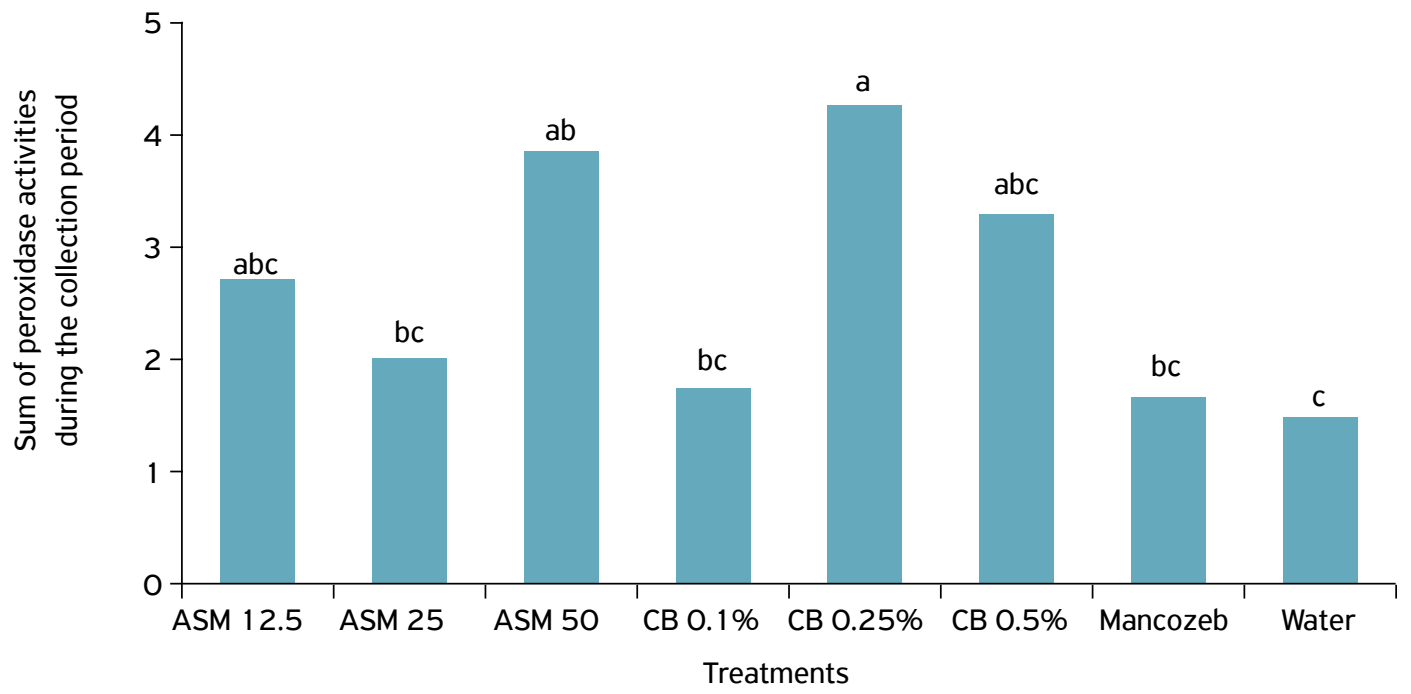

ASM 12.5: acibenzolar-S-methyl (ASM) $12.5 \mathrm{mg} \mathrm{L}^{-1}$; ASM 25: ASM $25 \mathrm{mg} \mathrm{L}^{-1}$; ASM 50: ASM $50 \mathrm{mg} \mathrm{L}^{-1}$; CB $0.1 \%$ : citrus biomass (CB) O.1\%; CB $0.25 \%$ : CB 0.25\%; CB 0.5\%: 0.5\%; mancozeb $\left(1.6 \mathrm{~g} \mathrm{~L}^{-1}\right)$. Columns followed by the same letter do not differ statistically from each other according to the Tukey test $(\mathrm{a}=0.01)$.

Figure 2. Sum of peroxidase activities in rocket (Eruca sativa) treated with abiotic inducers and inoculated with Albugo candida $\left(1 \times 10^{4}\right.$ sporangia $\left.\mathrm{mL}^{-1}\right)$. 


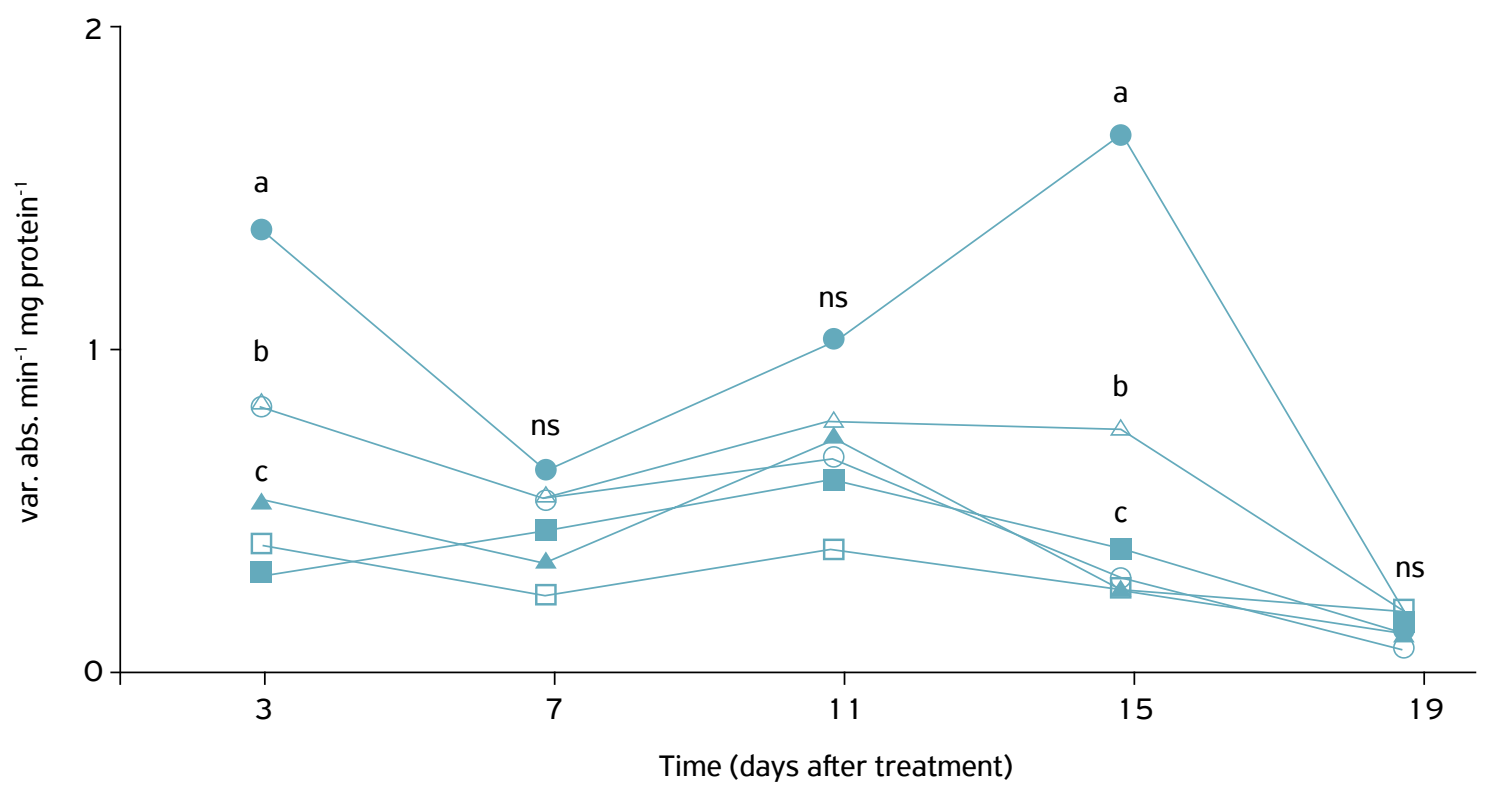

(-): Saccharomyces cerevisiae (25 mg mL-1); $(\square)$ : Bacillus thuringiensis (25 mg mL-1); $\left(\ominus\right.$ ): Saccharomyces boulardii $\left(25 \mathrm{mg} \mathrm{mL}^{-1}\right) ;(\triangle)$ : phosphorylated mannan oligosaccharide; $(-)$ : bordeaux mixture 1\%; (-): Water. Averages, at a given time, followed by the same letter do not differ statistically from each other according to the Tukey test $(a=0.01)$. ns: not significant.

Figure 3. Specific peroxidase activity in rocket (Eruca sativa) treated with biotic inducers and inoculated with Albugo candida $\left(1 \times 10^{4}\right.$ sporangia $\left.\mathrm{mL}^{-1}\right)$.

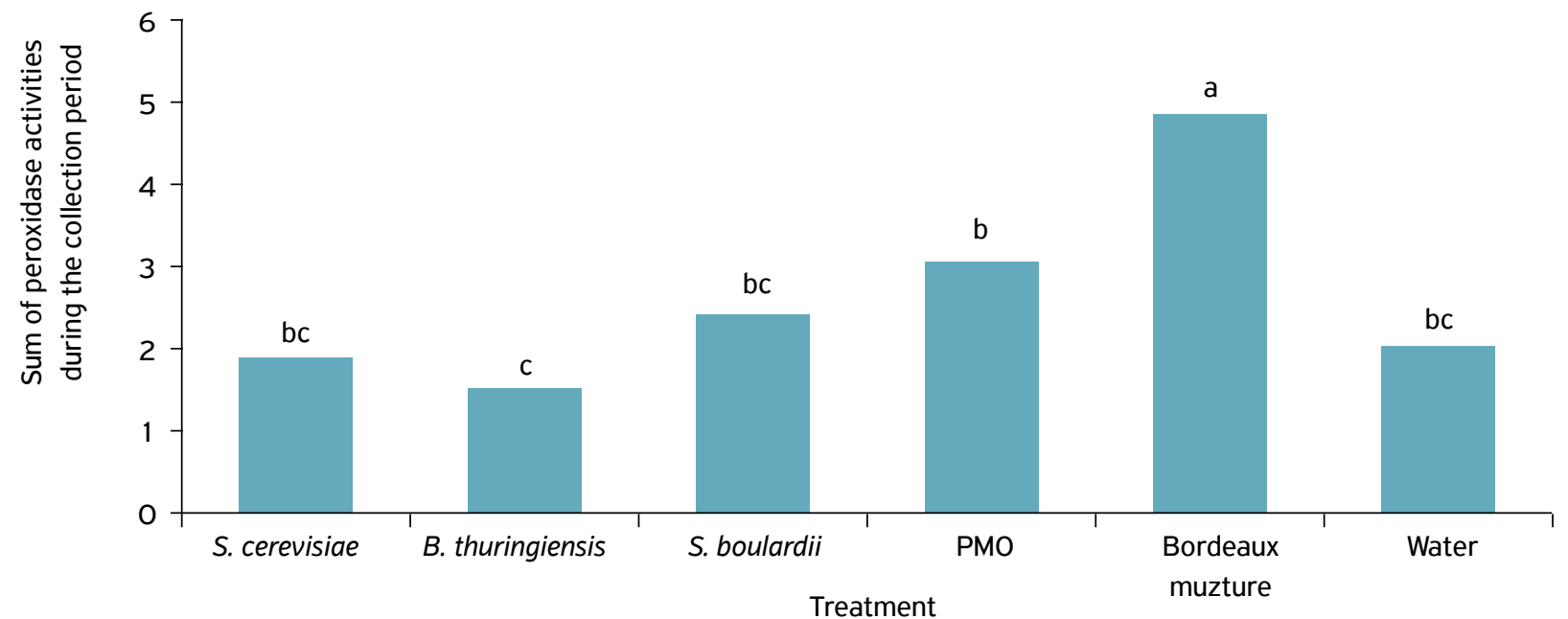

S. cerevisiae (25 mg mL-1); B. thuringiensis ( $25 \mathrm{mg} \mathrm{mL}^{-1}$ ); S. boulardii ( $25 \mathrm{mg} \mathrm{mL}^{-1}$ ); PMO: phosphorylated mannan oligosaccharide; bordeaux mixture: $1 \%$. Columns followed by the same letter do not differ statistically from each other according to the Tukey test $(a=0.01)$.

Figure 4. Sum of peroxidase activities in rocket (Eruca sativa) treated with biotic inducers and inoculated with Albugo candida $\left(1 \times 10^{4}\right.$ sporangia $\left.\mathrm{mL}^{-1}\right)$.

and mancozeb increased the disease control and productivity in tubers. For the cultivar Baraka, treatments with mancozeb resulted in a relative increase by up to $66.7 \%$. Similarly, the cultivar Asterix presented increases by up to $43.9 \%$ with chlorothalonil and $46.7 \%$ with mancozeb.

\section{CONCLUSION}

Acibenzolar-S-methyl, citric biomass, and phosphorylated mannan oligosaccharide can potentially control white rust in rocket and increase peroxidase activity. 
ACKNOWLED GEMENTS: Not applicable.

FUNDING: This work did not receive any specific grant from funding agencies in the public, commercial, or not-for-profit sectors.

CONFLICTS OF INTEREST: All authors declare that they have no conflict of interest.

ETHICAL APPROVAL: Not applicable.

AVAILABILITY OF DATA AND MATERIAL: All data generated or analyzed during this study are included in this published article.

AUTHORS' CONTRIBUTIONS: Methodology, writing — original draft, writing — , review and editing, formal analysis, investigation, visualization: lurkiv, L.; Eckstein, B. Data curation, writing — original draft, writing — , review and editing, software, visualization: Lorenzetti, E. Project administration, supervision, validation, review, editing, conceptualization, resources, visualization: Stangarlin, J.

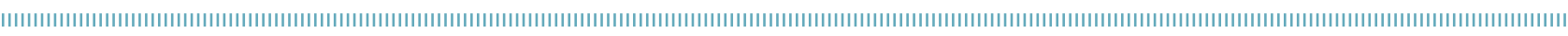

\section{REFERENCES}

BRADFORD, M.M. A rapid and sensitive method for the quantitation of microgram quantities of protein utilizing the principle of proteindye binding. Analytical Biochemistry, v.72, p.248-254, 1976. http://dx.doi.org/10.1006/abio.1976.9999

CAVALCANTI, L.S.; BRUNELLI, K.R.; STANGARLIN, J.R. Aspectos bioquímicos e moleculares da resistência induzida. In: CAVALCANTI, L.S.; DI PIERO, R.M.; CIA, P.; PASCHOLATI, S.F.; RESENDE, M.L.V.; ROMEIRO, R.S. (Eds.). Indução de resistência em plantas a patógenos e insetos. Piracicaba: FEALQ, 2005. p.81-124.

CAVALCANTI, F.R.; RESENDE, M.L.V.; ZACARONI, A.B.; RIBEIRO JÚNIOR, P.M.; COSTA, J.C.B.; SOUZA, R.M. Acibenzolar-S-metil e Ecolife ${ }^{\circledR}$ na indução de respostas de defesa do tomateiro contra a mancha bacteriana (Xanthomonas vesicatoria). Fitopatologia Brasileira, Brasília, v.31, n.4, p.372-380, 2006. http://dx.doi. org/10.1590/SO100-41582006000400007

COSTA, M.J.N.; ZAMBOLIM, L.; RODRIGUES, F.A. Avaliação de produtos alternativos no controle da ferrugem do cafeeiro. Fitopatologia Brasileira, Brasília, v.32, n.2, p.150-155, 2007. http://dx.doi.org/10.1590/SO100-41582007000200010

DANTAS, S.A.F.; OLIVEIRA, S.M.A.; BEZERRA NETO, E.; COELHO, R.S.B.; SILVA, R.L.X. Indutores de resistência na proteção do mamão contra podridões pós-colheita. Summa Phytopathologica, Botucatu, v.30, n.3, p.314-319, 2004.

FERREIRA, D.F. Sisvar: a computer statistical analysis system. Ciência e Agrotecnologia, Lavras, v.35, n.6, p.1039-1042, 2011. http://dx.doi.org/10.1590/S1413-70542011000600001

HAMMERSCHMIDT, T.R.; NUCKLES, E.M.; KUĆ, J. Association of enhanced peroxidase activity with induced systemic resistance of cucumber to Colletotrichum lagenarium. Physiological Plant Pathology, Berlin, v.20, n.1, p.77-82, 1982. https://doi. org/10.1016/0048-4059(82)90025-X
JESUS, C.O.; GUZZO, S.D.; HARAKAVA, R. Indução de resistência em cafeeiro a Hemileia vastatrix por isolados de Bacillus thuringiensis e proteína harpina. Summa Phytopathologica, Botucatu, v.34 (suplemento), p.54-54, 2008.

JESUS, C.O.; LUCON, C.M.M.; GUZZO, S.D.; PASCHOLATI, S.F. Efeito de isolados de Bacillus thuringiensis e de proteína harpina no controle de Phyllosticta citricarpa em frutos de laranja. Summa Phytopathologica, Botucatu, v.32 (suplemento), p.81-81, 2006.

LABANCA, E.R.G. Purificação parcial de elicitores presentes em Saccharomyces cerevisiae: atividade como indutores de resistência em pepino (Cucumis sativus) contra Colletotrichum lagenarium e da síntese de gliceolinas em soja (Glycine max). 2002. 107p. Dissertation (Master's degree in Agronomy) - Escola Superior de Agricultura Luiz de Queiroz, Piracicaba, 2002.

LYON, G.D.; NEWTON, A.C. Do resistance elicitors offer new opportunities in integrated disease control strategies? Plant Pathology, Washington, v.46, n.5, p.636-641, 1997. https:// doi.org/10.1046/j.1365-3059.1997.d01-63.x

MEENA, R.L.; JAIN, K.L.; RAWAL, P. Evaluation of rapessed-mustard genotypes for resistance to white rust (Albugo candida). Resistant Pest Managemente Newsletter, East Lansing, v.14, n.2, p.29-30, 2005.

MÉTRAUX, J.P. Induced defenses in plants. In: RODRIGUES, F.A.; ROMEIRO, R.S. Indução de resistência em plantas a patógenos. Viçosa: Suprema, 2007. p.7-24.

NICHOLSON, R.L.; HAMMERSCHMIDT, R. Phenolic compounds and their role in disease resistance. Annual Review of Plant Pathology, Palo Alto, v.30, p.369-389, 1992. https://doi.org/10.1146/ annurev.py.30.090192.002101

PASCHOLATI, S.F.; DALIO, R.J.D. Fisiologia do Parasitismo: como as plantas se defendem dos patógenos. In: AMORIM, L.; REZENDE, J.A.M.; BERGAMIN FILHO, A. Manual de fitopatologia: princípios e conceitos. Ouro fino: Agronômica Ceres, 2018. p.423-452. 
PICCININ, E.; DI PIERO, R.M.; PASCHOLATI, S.F. Efeito de Saccharomyces cerevisiae na produtividade de sorgo e na severidade de doenças foliares no campo. Fitopatologia Brasileira, Brasília, v.30, n.1, p.5-9, 2005. http://dx.doi.org/10.1590/ So $100-41582005000100001$

REGHIN, M.Y.; OTTO, R.F.; OLINIK, J.R.; JACOBY, C.F.S. Efeito do espaçamento e do número de mudas por cova na produção de rúcula nas estações de outono e inverno. Ciência e Agrotecnologia, Lavras, v.29, n.5, p.953-959, 2005. https://doi.org/10.1590/ S1413-70542005000500006

RODRIGUES, A.A.C.; BEZERRA NETO, E.; COELHO, R.S.B. Indução de resistência a Fusarium oxysporum f. sp. tracheiphilum em caupi: eficiência de indutores abióticos e atividade enzimática elicitada. Fitopatologia Brasileira, Brasília, v.31, n.5, p.492-499, 2006. https://doi.org/10.1590/S0100-41582006000500009

ROSA, R.C.T.; COELHO, R.S.B.; TAVARES, S.C.C. DE H.; CAVALCANTI, V.A.L.B. Efeito de indutores no controle de míldio em Vitis labrusca. Summa Phytopathologica, Botucatu, v.33, n. 1, p.68-73, 2007. https://doi.org/10.1590/SO100-54052007000100010

SCHULZ, D.G.; STANGARLIN, J.R.; FRANZENER, G.; KUHN, O.J. Influência do tempo de cultivo de Saccharomyces boulardii na indução de fitoalexinas em soja e sorgo. Summa Phytopathologica, Botucatu, v.34 (suplemento), p.13-14, 2008.
SOARES, R.M.; MARINGONI, A.C.; LIMA, G.P.P. Ineficiência acibenzolar-S-metil na indução de resistência de feijoeiro comum à murcha-de-Curtobacterium. Fitopatologia Brasileira, Brasília, v.29, n.4, p.373-377, 2004. http://dx.doi.org/10.1590/ SO $100-41582004000400002$

STANGARLIN, J.R.; IURKIV, L. Ferrugem branca ataca rúcula. Revista Campo \& Negócio, Uberlândia, n.59, p.6-6, 2008.

STANGARLIN, J.R.; SCHULZ, D.G.; FRANZENER, G.; ASSI, L.; SCHWAN-ESTRADA, K.R.F.; KUHN, O.J. Indução de fitoalexinas em soja e sorgo por preparações de Saccharomyces boulardii. Arquivos do Instituto Biológico, São Paulo, v.77, n. 1, p.91-98, 2010.

TAIZ, L.; ZEIGER, F. Fisiologia Vegetal. Metabólitos secundários e defesa vegetal. 3. ed. Porto Alegre: Artmed, 2004.

TÖFOLI, J.G.; KUROZAWA, C.; DOMINGUES, R.J. Ação de fungicidas em diferentes fases do ciclo da pinta preta do tomateiro em condições controladas. Summa Phytopathologica, Botucatu, v.31, n.2, p.125-132, 2005.

VAN LOON, L.C.; VAN STRIEN, E.A. The families of pathgenesisrelated proteins, their activities, and comparative analysis of PR-1 type proteins. Physiological and Molecular Plant Pathology, v.55, n.2, p.85-97, 1999. https://doi.org/10.1006/ pmpp. 1999.0213 